\title{
EMPTYING THE COFFERS: OLD MONEY TO BUILD NEW RAILWAYS, SPAIN 1850-1874
}

\section{Abstract}

This paper analyzes the evolution of the Spanish economy during the third quarter of the nineteenth century, the critical initial phase of its modern development. The specific aim of the paper is to discuss the role to be awarded to foreign and domestic capital in financing the investment boom in those years. The main hypothesis stresses that the mobilization of savings previously accumulated and hoarded in gold was a distinctive and important origin of resources. This result challenges older assumptions about the economic changes of the period, and provides a vision somewhat different of the first steps of Spain's economic modernization.

\section{Introduction}

Since its beginnings as an academic field, Spanish economic history has pointed to the third quarter of the nineteenth century as a crucial initial phase in the country's long journey to modernity or, in Tortella's terms, the 'origins of capitalism in Spain'. Recently, a number of contributions about the period have appeared. Most are devoted to build new macroeconomic estimates or to refine the old ones.

Without openly calling for debate, the results of some of these studies challenge older hypotheses about the economic changes that characterized the period. The aim of this paper is to discuss one of these issues: the role that should be given to foreign and domestic capital in the financing of the investment boom in those years. The result points to the mobilization of accumulated savings as a distinctive and important source of resources. A somewhat different overall picture of Spanish first step for economic modernization emerges.

\section{The challenge of building credible estimates}

As is well known, recent decades have witnessed a prolonged and collective effort to construct a framework for quantitative historical estimates of the Spanish economy that has resulted in the first complete set of results thanks to the work of Leandro Prados. The two cornerstones of this new quantitative approach are, on the one hand, estimates of GDP and its components and, on the other hand, a reconstruction of the balance of payments ${ }^{1}$.

The new GDP estimates have primarily been built by means of reconstructing the physical production or consumption of each component and applying an appropriate set of fixed prices.

\footnotetext{
${ }^{1}$ Prados (2003 and 2010)
} 
The results, if not beyond criticism, have been widely accepted as the most accurate approach possible, given the available data ${ }^{2}$.

Even greater difficulties have had to be overcome to calculate the components of the balance of payments. Imports and exports had been estimated by Prados himself some years ago, but the other entries in the current account needed a great deal of ingenuity to be estimated. Income provided by freights and insurances was derived from maritime transport data; emigrant transfers drew on estimates of Spanish migration to Latin America; and tourism income was calculated working backwards from the first official estimate, that of Fernando Jáinaga for the 1930s. In any case these were minor entries in the overall balance. Much more relevant were the flows related to foreign investments (external debt service, interest paid on railway bonds held by foreigners, and returns and dividends paid by foreign-owned companies). After carefully weighting all the alternatives, Prados chose to build a direct estimate, using the literature on foreign investment in Spain.

The main goal of Prados' calculations was to give an estimate of Spain's international position. The last step was to subtract the balance of payments on the current account from the movements in the country's metallic money stock in order to obtain the capital account balance or net capital inflow. To do this, Prados took three estimates of gold and silver stock provided by Tortella (1850-1873) and Tortella and Martín-Aceña (1873-1900) and MartinAceña (1900-1913). As we will see, this last step could have been perhaps too risky because of the speculative nature of Tortella's calculations ${ }^{3}$. And because the calculation of capital inflows derived from this unsafe calculation is then used by Prados to build new estimates of domestic and foreign savings shares in overall investment, the latter also need to be treated with extreme caution.

Recently, Pedro Tedde has presented new estimates for several of Spain's external balance items for the period 1850-1874, including inflows of foreign capital and payments abroad for interests and profits ${ }^{4}$. In both cases he has made a direct estimate using the available data. The proposal of Tedde seems to me much more reliable than that of Prados, especially with respect to the capital account balance. The robustness of the new estimate relies on a careful analysis of specific studies and contemporary data for each relevant sector. Despite not being noted by the authors, the new estimates have implications for other variables as well and they paint a new panorama for the whole Spanish economy of the time.

\footnotetext{
2 See, for instance, the comments of Carreras (2004) and Maluquer de Motes (2005).

${ }^{3}$ Surprisingly, after such a careful process of calculation, Prados did not discuss whether these crucial estimates were reliable. Tortella's calculation of gold and silver stock for 1850-1873 has not been published by Tortella himself. A first approach appeared as 'preliminary results' in a book edited by Fremdling and O'Brien in 1983. Definitive results for 1848-1874 were published without further information by Martin Aceña in 2000. The complete series (1830-1874) has been finally included by Martín Aceña and Pons (2005) in the last edition of a statistical repository (p. 678). Some details and criticism can be found in the appendix to Moro, Nuño and Tedde (2015) .

4 Tedde (2015, pp. 171-175). There are some discrepancies between the estimates included in this book and those published previously in an article in this journal (Moro, Nuño and Tedde, 2015). Some of those differences seem related to the use of nominal or selling values of the private or state bonds issued abroad. I am going to use the estimate most recently published, Tedde (2015, pp. 171-175). As this paper is concerned with effective money flows, I take the estimation labelled as 'effective value' of capital entries (Table VI.2 p. 174).
} 
Before analyzing the changes, let us specify the interactions between the variables by means of a simplified set of equations. Taking the usual macroeconomic identities, we have:

$$
G D P=C+G+I+X-M(+V)
$$

where GDP is gross domestic product; C, consumption; I, gross investment; G, government spending; $X$, exports of goods and services; $M$, imports of goods and services; and $V$, net returns on foreign factors.

Income can either be consumed, saved, taxed or transferred abroad as follows:

$$
G D P=C+S_{p}+T+T r
$$

where $S_{p}$ are private savings; T, government taxes; and Tr, net tranfers abroad. We can then define the current account balance (CAB) as:

$$
C A B=X-M+V-T r
$$

Taking these expressions and rearranging them, we have:

$$
I=S_{p}-(G-T)-C A B \quad \text { or } \quad I=S_{p}-B D-C A B
$$

and then:

$$
I=S_{t}-C A B
$$

where BD is government deficit; and $\mathrm{S}_{\mathrm{t}}$ represents the country's gross savings (private savings less the government deficit).

That is, the amount invested equals savings less the current account balance.

We introduce now the capital account balance $K A B$, with two components: foreign capital for private business $\left(K A B_{p}\right)$ and funds for the state $\left(K A B_{g}\right)$, and TB as the total external balance, we have:

$$
T B=C A B+K A B_{p}+K A B_{g}
$$

Finally, as external imbalances had to be settled in metallic money, we can state that

$$
\boldsymbol{T B}=\Delta \boldsymbol{H}^{s}
$$

So, the external balance has to equal the increases or decreases in the stock of metallic money and, as a consequence, rearranging, we have:

$$
I+B D=S_{p}+\left(K A B_{p}+K A B_{g}\right)-\Delta H^{s}
$$

This identity can be understood as defining the ways the financial needs of the country can be fulfilled. Investment plus state deficit could be financed through domestic savings, entries of foreign capital, and decreases in the money stock. 
We can now return to the works of Prados and Tedde. The different strategies adopted in the two approaches can be summarized as follows:

\begin{tabular}{|l|l|l|}
\hline & Prados & Tedde \\
\hline Own independent estimation & $\mathrm{C} ; \mathrm{G} ; \mathrm{I} ; \mathrm{X} ; \mathrm{M} ; \mathrm{V} ; \mathrm{Tr}[\mathrm{CAB} ; \mathrm{GDP}]$ & $\mathrm{V} ;[\mathrm{CAB}] ; \mathrm{KAB}$ \\
\hline Taken from others & $\mathrm{TB}$ (from Tortella) & $\mathrm{C} ; \mathrm{G} ; \mathrm{I} ; \mathrm{X} ; \mathrm{M} ; \operatorname{Tr}[\mathrm{GDP}]$ (from Prados) \\
\hline Deduced & $\mathrm{S} ; \mathrm{KAB}$ & $\mathrm{S} ; \mathrm{TB}$ \\
\hline
\end{tabular}

We have two direct estimates of $V$ and, subsequently, of $C A B$, but they are slightly different. The major divergence is between accepting Tortella's estimate of money stock movements and deducing KAB (Prados); or, conversely, estimating KAB and deducing the money stock fluctuations (Tedde).

Note that the main macroeconomic aggregates (GDP; investment) are not in question, so it is worthwhile looking at them before dealing with the discrepancies. Figure 1 shows the evolution of gross domestic product and gross investment according to Prados.

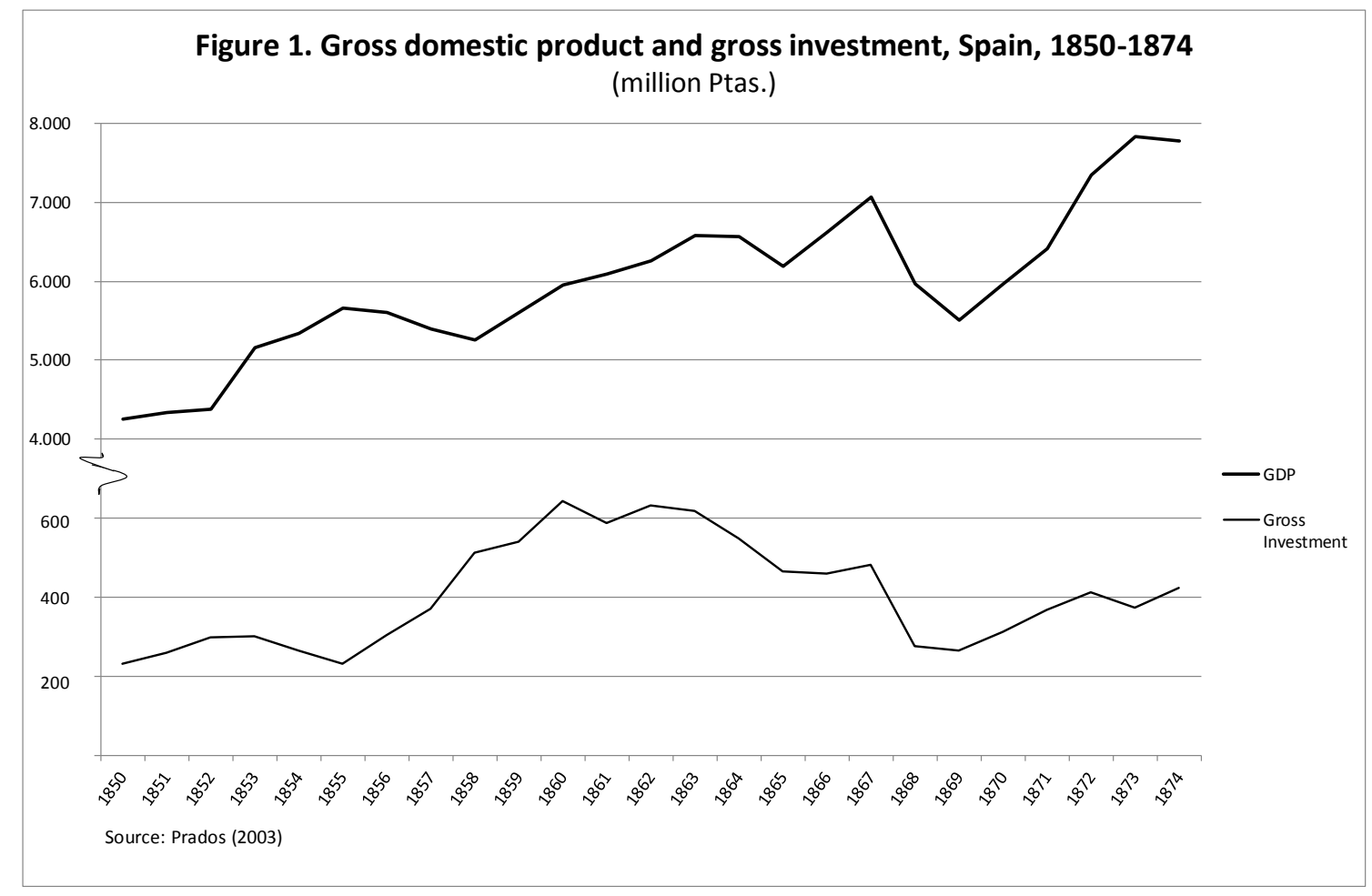

Although both series reflect some shocks in similar terms, such as the effects of the Revolution of 1868, they are in fact very different. GDP grew steadily until the Revolution and resumed its upward movement after a brief decline. Investment, on the contrary, shows a typical boom form, returning to only a little more than its starting levels, after having doubled in the years of the railway 'mania'. As a consequence, at the end of the period analyzed, the rate of investment over total income was lower (5.3 per cent) than at the beginning (6.0 per cent). Over the interval, the investment ratio surpassed 10 per cent more than once. 
How this investment was financed stands at the center of the controversy. Table 1 shows the results obtained using both estimates.

Table 1. Gross investment and inflows of foreign capital. Spain, 1850-1874

\begin{tabular}{|c|c|c|c|c|c|}
\hline \multicolumn{6}{|c|}{ (Million Ptas., and \%) } \\
\hline & & & & Entries of & Entries of \\
\hline & & & & foreign & foreign \\
\hline & & & & capital & capital \\
\hline & & Entries of & Entries of & (private) o/ & (private) o/ \\
\hline & & foreign & foreign & total & total \\
\hline & Gross & capital & capital & investment & investment \\
\hline & Investment & (private) & (private) & (\%) & (\%) \\
\hline & (Prados) & (Prados) & (Tedde) & (Prados) & (Tedde) \\
\hline $1850-1854$ & $1,353.4$ & 402.7 & 5.0 & 29.8 & 0.4 \\
\hline $1855-1859$ & $1,957.9$ & 712.0 & 302.3 & 36.4 & 15.4 \\
\hline $1860-1864$ & $3,027.9$ & $1,414.7$ & 568.2 & 46.7 & 18.8 \\
\hline $1865-1869$ & $1,945.5$ & 388.8 & 96.4 & 20.0 & 5.0 \\
\hline $1870-1874$ & $1,891.4$ & 19.9 & 284.0 & 1.1 & 15.0 \\
\hline
\end{tabular}

Note 1: Prados (2010) only provides agregate net entries of foreign capital. I have substracted entries due to public debt from Tedde $(2015$, p. 174$)$ to calculate private flows.

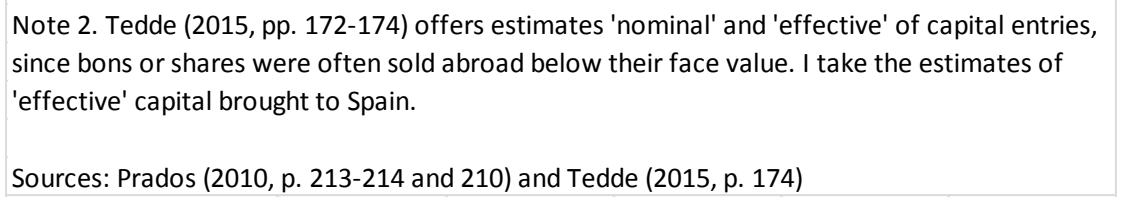

As can be seen, Tedde proposal results in a sizable reduction in the foreign capital inflows assumed by Prados. We find that during the bulk of the investment 'boom' (1855-1864) the contribution of foreign capital entries to finance investment falls by more than a half, from 42,7 per cent to a small 17,5 . This result openly contradicts one of the centerpieces of the mainstream interpretation of Spain's nineteenth-century economic development, which gives foreign capital a principal role in the origins of Spanish modernization.

In fact, the crucial role of foreign capital has been until now a wholly accepted feature of Spanish economic development during the second half of the ninetieth century. Competing explanations differ about agriculture backwardness; effects of protectionist policies, consequences of State deficit or inequality, but everyone seems to accept that a massive entry of French and British capital was a decisive factor through two main ways: bringing badly needed capital and helping to introduce new technologies and management skills. The classical works of Sardà, Tortella and Nadal, and the monumental research of Albert Broder, among others, left this as an apparently well-established principle that has not been challenged afterwards ${ }^{5}$.

But if the role of foreign capital becomes so greatly diminished, how was the investment boom of those years actually financed? Equations [4] and [7] allow us to offer an answer according to both estimates. Table 2 shows the results.

\footnotetext{
${ }^{5}$ Sardà (1948); Tortella (1973, 1977); Nadal (1973, 1975); Broder (1976, 1981). More recent interpretations of Spanish development during the XIX century in Prados and Rosés (2009); Carreras and Tafunell (2010) or Tortella (2010)
} 


\begin{tabular}{|c|c|c|c|c|c|c|c|c|}
\hline \multicolumn{8}{|c|}{ Table 2. Financial needs and origin of resources (million Ptas) } & \multirow{3}{*}{$\begin{array}{c}\text { Variation on } \\
\text { the stock of } \\
\text { metallic } \\
\text { money* }\end{array}$} \\
\hline & \multirow{2}{*}{$\begin{array}{c}\text { Total } \\
\text { Investment }\end{array}$} & \multirow{2}{*}{$\begin{array}{c}\text { Government } \\
\text { deficit }\end{array}$} & \multirow{2}{*}{$\begin{array}{c}\text { Total financial } \\
\text { needs }\end{array}$} & \multirow{2}{*}{$\begin{array}{l}\text { Private } \\
\text { savings }\end{array}$} & \multicolumn{3}{|c|}{ Entries of foreign capital } & \\
\hline & & & & & private & public & Total & \\
\hline \multicolumn{9}{|c|}{ Own calculation on Prados estimates } \\
\hline $1850-1854$ & $1,353.4$ & 71.0 & $1,424.4$ & $1,038.7$ & & & 467.7 & 82.0 \\
\hline 1855-1859 & $1,957.9$ & 208.0 & $2,165.9$ & $1,657.9$ & & & 712.0 & 204.0 \\
\hline $1860-1864$ & $3,027.9$ & 633.0 & $3,660.9$ & $2,660.3$ & & & $1,414.7$ & 414.1 \\
\hline $1865-1869$ & $1,945.5$ & 777.0 & $2,722.5$ & $2,213.7$ & & & 820.9 & 312.1 \\
\hline $1870-1874$ & $1,891.4$ & $1,025.0$ & $2,916.4$ & $2,416.6$ & & & 542.1 & 42.3 \\
\hline \multicolumn{9}{|c|}{ Own calculation on Tedde estimates } \\
\hline & & & & & & & & \\
\hline $1850-1854$ & $1,353.4$ & 71.0 & $1,424.4$ & $1,127.3$ & 5.0 & 65.0 & 70.0 & 227.1 \\
\hline $1855-1859$ & $1,957.9$ & 208.0 & $2,165.9$ & $1,786.1$ & 302.3 & & 302.3 & 77.5 \\
\hline $1860-1864$ & $3,027.9$ & 633.0 & $3,660.9$ & $2,929.2$ & 568.2 & & 568.2 & 163.5 \\
\hline $1865-1869$ & $1,945.5$ & 777.0 & $2,722.5$ & $2,351.2$ & 96.4 & 432.1 & 528.5 & 157.2 \\
\hline $1870-1874$ & $1,891.4$ & $1,025.0$ & $2,916.4$ & $2,597.5$ & 284.0 & 562.0 & 846.0 & 527.1 \\
\hline \multicolumn{9}{|c|}{ * negative value signifies increase and positive reduction } \\
\hline & & & & & & & & \\
\hline Sources. Ow & calculation o & data from Pra & dos (2010) and T & (2015) & & & & \\
\hline
\end{tabular}

As could be expected, a shrinking foreign capital contribution implies a complete reversal of the role played by variations in the stock of metallic money. Tortella's estimations were based on an expected increase in the metallic money stock, and we find now that we need a decrease to explain the whole external equilibrium. In other words, domestic savings and foreign capital were not enough to pay for the wave of investment; it would have to be partly paid out through outflows of metallic money or, as I will subsequently argue, by mobilizing hoarded money that had previously been saved.

As we will comment later with some detail, this great wave of investment was related to changes in government policies and on the availability of domestic and foreign investors. Nevertheless, the role of the state was well beyond of passing an encouraging regulation. Through diverse ways, the government was able to transfer to railways companies a fair amount of money and to increase at the same time direct investment in other infrastructures. 


\begin{tabular}{|l|l|l|l|l|r|}
\hline & & \\
\\
\hline
\end{tabular}

In his classical study on Spanish public sector, Francisco Comín after a detailed discussion accepts a previous estimate of the money transferred to railway companies by the state by a total amount of 456 million pesetas until $1874^{6}$. As Comín himself points out, most of these transfers cannot be considered investment, as were assigned to complement insufficient current earnings ${ }^{7}$. Nevertheless comparison with other magnitudes reminds us about of the importance of State action in this issue.

Working on Comín data, Prados has produced separate estimates for public and private investment (Table 4). Firstly is worth to emphasize that the participation of the State as investor was not in any way negligible. In the pick of the investment wave, public action contributed with almost a quarter of all resources devoted to capital formation. In fact public investment grew a lot faster than private during those years. Railways were the main recipients of these resources, but other infrastructures, like roads or harbors also took a good share of public activism ${ }^{8}$. This period was something as a golden age for Spanish public investment.

\footnotetext{
${ }^{6}$ Comín (1988, I, p. 374)

${ }^{7}$ Comín $(1988$, I, p. 382)

8 See Herranz-Loncán (2004) for a complete approach to the investment on infrastructures.
} 


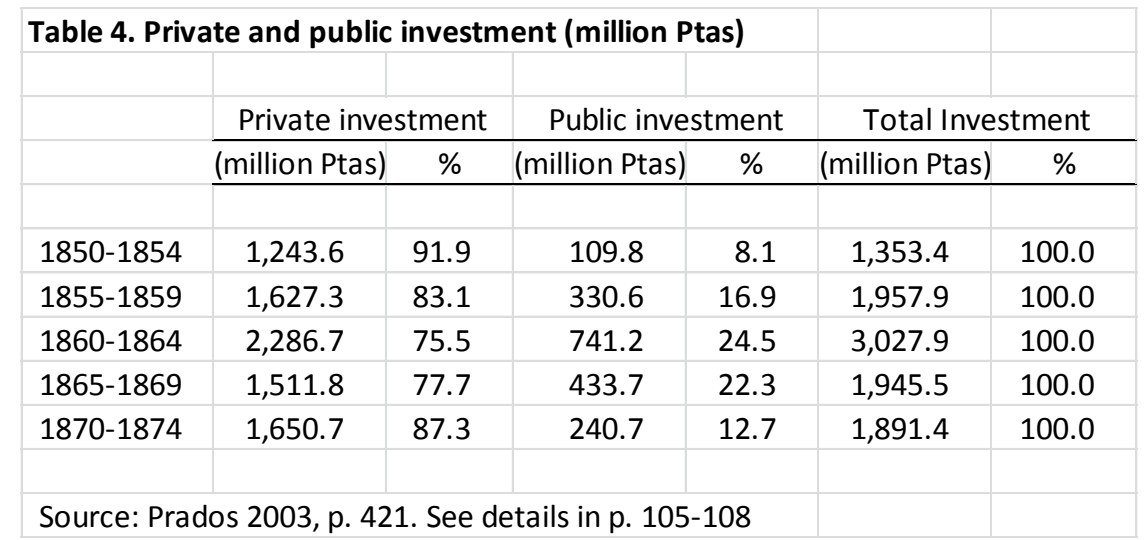

Unfortunately, the effort to build new infrastructures was not accompanied by a parallel reform of the State fiscal capacity. As a result, not only public investment was not adequately funded, but current deficit itself also grew to very high levels, both in absolute and relative terms. The new issuance of external public debt in the last year of the period could not be but a weak puff of fresh air for an already suffocated body.

The main consequence of this contradiction between goals and means of the Spanish state was that private sector had to charge with all the financial burden of both public investment and current state deficit. It is not surprising that private savings and foreign capital entries were not enough to cope with such an increase of the demand for funds. Drain of metallic money stock became inevitable.

Coming back to Tables 2 and 3 we can identify three distinct episodes in the global financial equilibrium of the Spanish economy between 1850 and 1874 . The first one would run between 1850 and 1856, and could be characterized as the first burst of modern investment. Although we have not a set of estimates that did allow us to evaluate the volume of this first investment increase, its existence seems hard to deny. Two relevant indicators point out in the same direction. Investment in infrastructures multiplied by three between 1845-1849, and 1850-54 in real terms ${ }^{9}$; and entrepreneurial investment in Catalonia did so by almost the same proportion between $1840-1848$ and $1849-1857^{10}$.

Private savings were not strong enough to finance this first investment surge, and it was not possible to resort to international capital markets, closed for Spanish securities after the 'arreglo' (partial default) of 1851. The subsequent loss of money stock could be related with a first wave of dishoarding. Between 1848 and 1854 not less than forty new corporations ('sociedades anonimas') were created, which launched to the market around 140 million pesetas in shares and bonds ${ }^{11}$. In addition, the reform of the state finances, despite the opposition of some foreign investors, made government bonds more secure and reliable, and consequently more suitable as a placement for people savings ${ }^{12}$.

\footnotetext{
${ }^{9}$ Herranz-Loncan (2004, p. 129)

10 Sudrià and Pascual (1999, p. 131)

${ }^{11}$ See Herranz-Loncan (2004, p. 129), for railways; Gaceta de los Caminos de Hierro, vol. 32 (14-Dec-1856), pp. 530532, for Catalonia; and, Anuario Estadístico de España, 1858.

12 See Comin (2014, pp. 159-166), for a new evaluation of this reform.
} 
As we will see later, the big railway and financial boom followed the progressive financial reform of 1856. In 1864-1866 investment attained annual levels that were, again, an $80 \%$ higher than those of ten years before. In this second phase, foreign capital played a very distinctive role, if not dominant in any way. In fact most of the financial effort of those years must be attributed to current domestic savings that increased from around 4,5\% to more than $10 \%$ of total income. From 1866 on foreign capital entries dramatically diminished and also private domestic savings showed some weakness. This situation worsened further with the outbreak of the last carlist war in 1872. Only the resort to a massive launch of external debt avoided a collapse and allowed the government to restore the metallic monetary stock depleted in previous periods.

Is this hypothesis implausible? Could these estimates be radically wrong? Despite the accuracy in its construction, estimates of aggregate magnitudes contain inevitably biases and errors that could induce to wrong interpretations. This might be more so in the case of the expenditure side of the national accounts. As is well known, estimates of the production side are considered less likely to contain major errors and, as a consequence, differences between both approaches are solved usually adjusting aggregate consumption. Prados followed this procedure in the case of the Spanish economy, but taking care to do not modify consumption internal composition ${ }^{13}$. As gross savings are deducted as a residual, any miscalculation of consumption would affect them.

\begin{tabular}{|l|l|l|}
\hline Table 5. Private Savings over GDP (\%) \\
\hline & $\begin{array}{c}\text { Private } \\
\text { domestic } \\
\text { savings } \\
\text { \% over GDP } \\
\text { (Prados) }\end{array}$ & $\begin{array}{c}\text { Required * } \\
\text { private domestic } \\
\text { savings } \\
\text { (New estimation) }\end{array}$ \\
\hline & & \\
\hline $1850-1854$ & 4.4 & 5.8 \\
\hline $1855-1859$ & 6.0 & 6.8 \\
\hline $1860-1864$ & 8.5 & 9.8 \\
\hline $1865-1869$ & 7.1 & 7.0 \\
\hline $1870-1874$ & 6.8 & 5.9 \\
\hline & & \\
\hline * Investment plus state deficit less entries of \\
\hline
\end{tabular}

Prados did not reveal nor the amount (if any) nor the sign of these adjustments. Nevertheless a look at the figures he proposes strongly supports the view that the more likely bias would result in an overvaluation of gross savings and not the converse. As can be seen in Table 5, Prados estimate implies a private savings rate over GDP during the boom close to 7-9 per cent. It is the highest of fifty years, not attained again until 1895-99, when per capita income was 50 per cent higher than in 1860. Using the new estimates of foreign capital entries and not allowing for a decrease in the stock for money, private savings would have to attain 10 per cent of the GDP in the central years to be able to finance investment, something much more

13 Prados (2003, p. 88) 
unlikely yet. From this point of view, the hypothesis of a different -non-current- source of savings appeared reinforced.

Another way to try to clarify this apparent paradox is to look to the particular experience of the more advanced Spanish region of the moment: Catalonia. This will be especially worthwhile precisely because the railway fever was there almost fully internally financed. The Catalan case has been studied using a different approach than those followed by the works cited earlier. The main goal was to construct an estimate of real investment carried out by registered companies, essentially using notary deeds ${ }^{14}$.

This procedure cannot capture the entire investment, since part of it was done by individuals, especially in real estate. Using independent studies it can be estimated that this unaccountedfor investment may add-up to a quarter of the total.

The results for companies' investment alone can be seen in Figure 2. As in the Spanish case, we see a huge increase in investment between 1856 and 1866 linked to railways, other infrastructure, and commercial activities. Unlike the Spanish case, however, foreign capital cannot be credited with Catalonia's investment boom except to a very small degree. As is well known, Catalan railways and other big undertakings were largely financed by Catalonia's internal savings. In all likelihood, the small amount of capital that came from abroad was more than offset by Catalan savers' participation in the financing of the Spanish railways ${ }^{15}$.

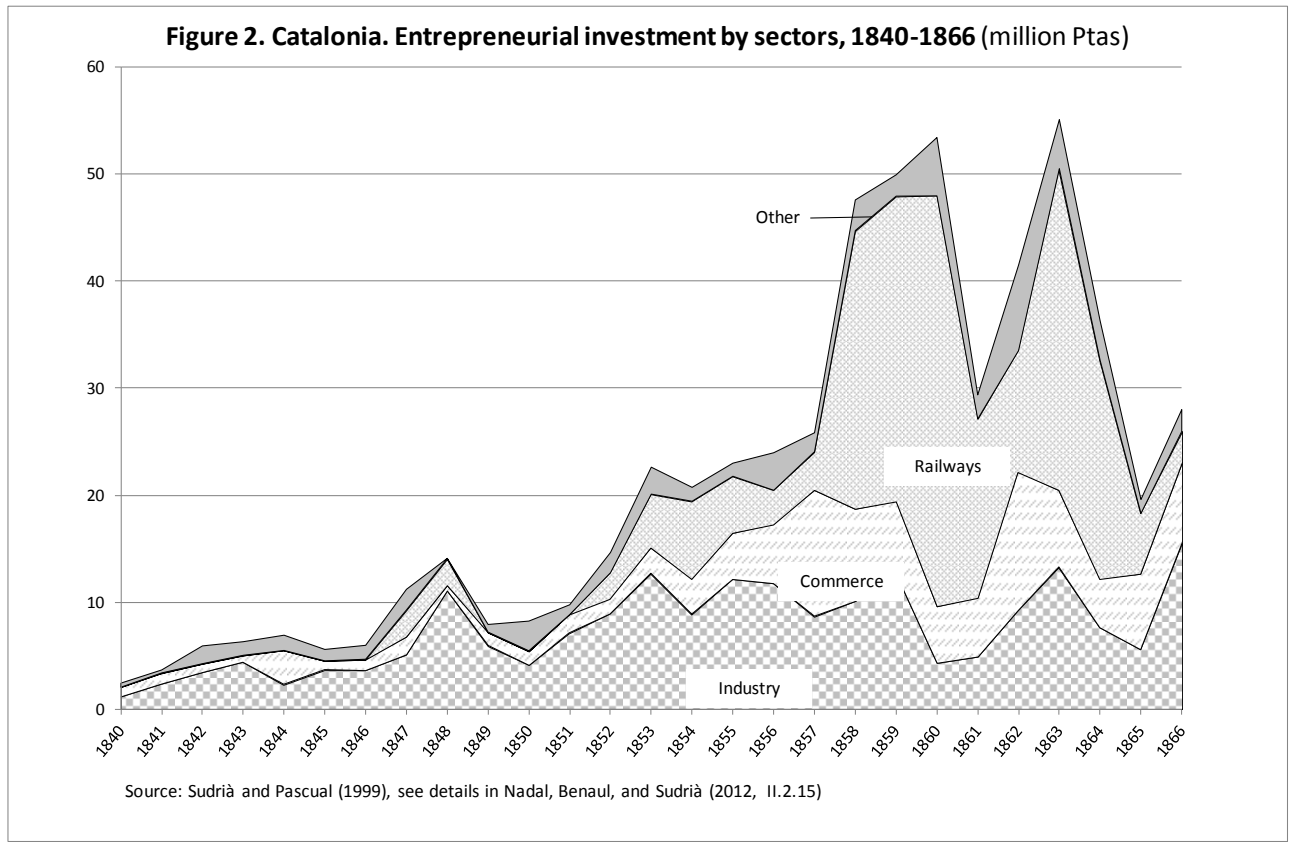

In this case too, the results show an investment level for the decade 1856-1866 that is incompatible with any credible rate of current savings. Catalonia's GDP for 1860 has been estimated at 708 million Ptas. So, if we take a rate of savings on GDP of about 5 per cent for

\footnotetext{
${ }^{14}$ Sudrià and Pascual (1999).

15 Pascual (1990, p. 210 and fol.); Pascual (1999, passim)
} 
1850 (a little higher than the obtained by Prados for whole Spain), and a 2.5 per cent growth rate, the ratio of investment/savings over GDP would have to attain around 10 per cent during the boom. Also in this case this would be a minimum, if we have in mind that most of real estate investments were financed by individuals and are not included in our estimates .

So, through different sources, research strategies, and procedures, we reach the same result. The intense investment process that took place in Spain during the third quarter of the nineteenth century could not be financed solely by foreign capital and current domestic savings. Only a drain of gold and silver can explain the gap. The amount of unaccounted-for resources is by no means negligible.

\section{The drain of metallic money and its consequences}

How significant could this drain be? And what consequences might it have? An estimate of the amount of metallic money in circulation between 1850 and 1874 can be deduced from the new estimates of external financial flows discussed earlier. Figure 3 shows the results to apply from 1874 backwards to 1850, the movements in metallic stock deduced from Tedde estimate. As expected, the evolution of metallic stock derived from the new estimates is completely opposite to Tortella's proposal. The threefold increase expected by Tortella stands in stark contrast to the new twofold movement, which reflects an almost 30\% decrease up to 1866, followed by a recovery due mostly to a new issuance of public debt.

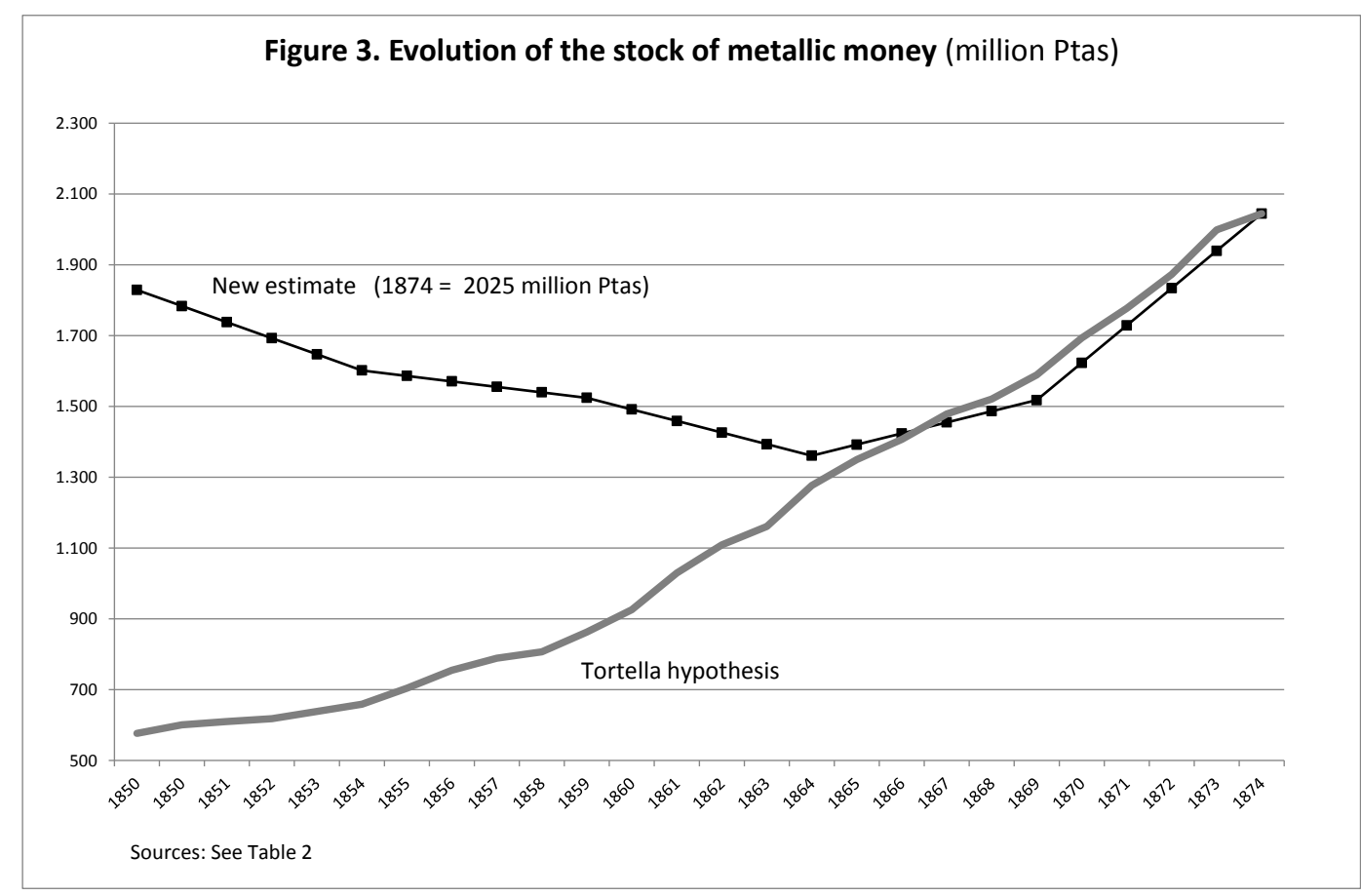

Such a loss of metallic money had to affect the money supply, especially in a financially backward economy like Spain's in those years. For a reliable approach to the money supply, we need to add so-called banking money to metallic money, that is, the means of payment created by banks through the issuing of banknotes and the acceptance of current accounts. 
Figure 4 shows that banking money, as expected, was still too small to compensate for the effect of movements in metallic money. The conclusion cannot be avoided: if we have confidence, as I do, in Prados' estimates (except for his estimate of external capital flows) and in Tedde estimates for external capital flows or for the whole external balance, we also have to accept that a sudden fall in money supply, almost by third, occurred between 1850 and 1866 . Is this fall consistent with the evolution of other indicators (prices, interest rates, etc.)? Can we reconcile these new findings with the overall economic understanding of the period?

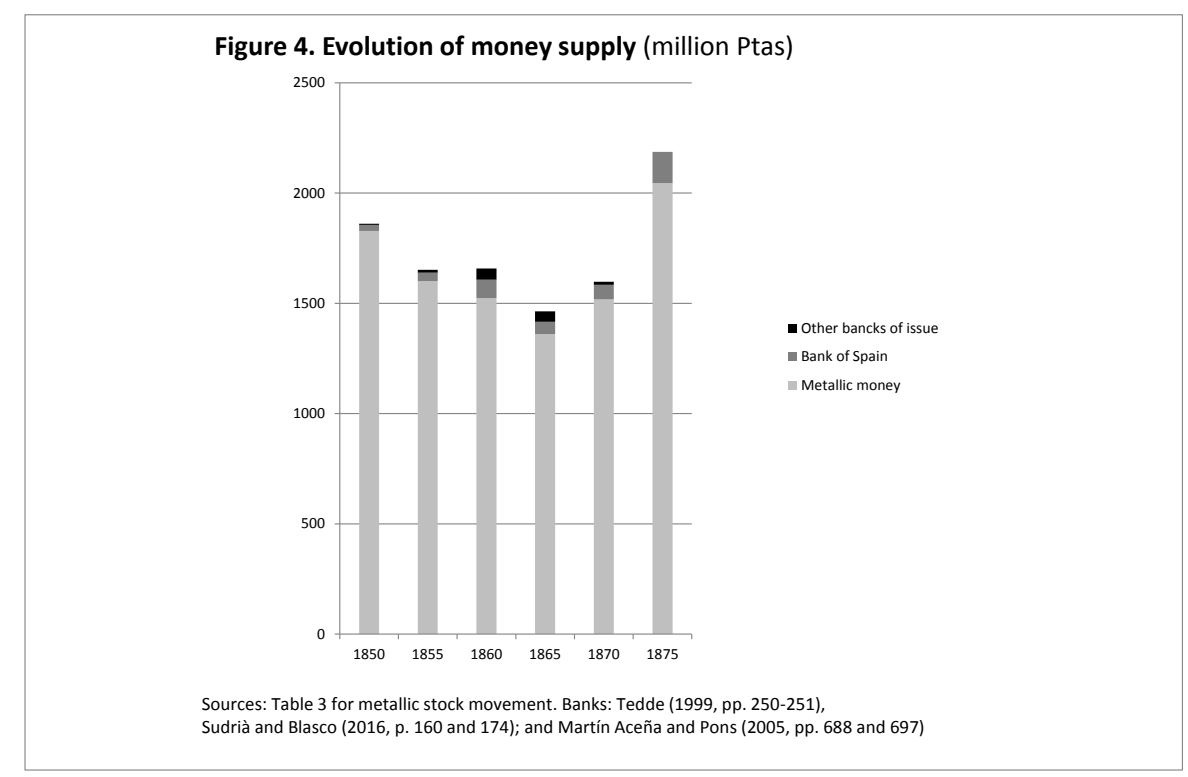

Looking first at prices, we find no symptoms of a fall in money supply. All three major estimates, those of Sardà, Prados and Maluquer, show an increase between 1850 and 1866, ranging from 30 to 50 per cent ${ }^{16}$. On the contrary, rising interest rates seem to reflect a reduction in the money supply. This rise has been associated in 1865 and 1866 to the gradual exhaustion of hoarded money well in advance of the completion of most rail lines ${ }^{17}$.

So, leaving aside the specific evolution of each variable, it is clear that none of the variables shows the expected response to such a sudden and major reduction in the money supply. Let us recall that during the financial distresses of the 1890s and 1930s, money supply contracted by roughly 13 percent and less than 4 percent, between peaks ( 4 years), and prices fell by roughly 10 and 3.5 per cent, respectively. Nothing similar seems to have happened with the reduction in the money supply in the mid-nineteenth century. Another question that needs an answer.

While not the case with some of the economic variables, the drain of metallic money deduced from the macroeconomic estimates does find confirmation in various contemporary sources, and in later sources as well. Tedde himself points out that well-informed contemporaries, like Santillan and Vázquez Queipo, were opposed to the idea that the metallic money stock was

\footnotetext{
16 Maluquer de Motes (2005, pp. 1288-1290).

${ }^{17}$ Sudrià and Pascual (1999); Navas and Sudrià (2008); Sudrià (2013).
} 
always growing, and also that Barthe (1909) estimated a loss of metallic money in circulation amounting to 300 million in the period $1856-1866^{18}$.

Contemporary evidence from other qualified witnesses reinforces the same impression. A well-known financial analyst, who used to publish a detailed and knowledgeable yearly report on Barcelona's financial activity, stated in 1865 that the rise of the changes was an incentive to acquire and extract French currency ${ }^{19}$. Later on, in March 1866, the British Embassy in Spain and the Barcelona consulate sent reports to the Foreign Office pointing out that money was being sent to Bayonne, Marseilles, and Paris, with an immediate benefit of from $1 \frac{1}{2}$ to $2 \frac{1}{2}$ per cent; and that this constant drain of bullion was gradually impoverishing the country and was the cause of very great pecuniary embarrassment and difficulties ${ }^{20}$.

The problems posed by the drain of metallic money impelled the Bank of Spain and the Government to try to compensate it bringing back gold from abroad. Those operations have been studied in detail by Pedro Tedde ${ }^{21}$. Usually they took the form of short-term credits for amounts that could hardly compensate for the imbalance caused by the investment boom ${ }^{22}$.

\section{A search for the missing money}

The hypothesis that this paper proposes as an answer to the foregoing questions can be stated as follows:

During the years under scrutiny an important amount of metallic money hitherto hoarded and kept out of circulation was mobilized through new kinds of financial instruments (corporate shares and bonds) distributed by a new kind of financial intermediary called sociedades de crédito. In this way savings from previous decades helped to finance railway investment, and allowed for a huge deficit in the overall external balance of payments and a large outflow of metallic money, without any perceptible decrease in money used as a means of exchange ${ }^{23}$.

Let us try to justify this hypothesis step by step, and explain some of its implications.

\footnotetext{
18 Tedde (2015, pp. 178-181); Moro, Nuño, and Tedde (2015, appendix B)

${ }^{19}$ Almanaque del Diario de Barcelona para el año 1965, p. 95.

20 Parliamentary Papers. Accounts \& Papers. Reports. Secretaries of Embassy, vol. LXXI (1866), pp. 446-447; Public Record Office (PRO), Foreign Office 72, 1.130 (18-1-1866). Reports from the French embassy and consulates include similar warnings. See, for instance, Sánchez-Albornoz (1962).

21 Tedde (2015, pp. 181-183)

22 Being short time operations, the gold introduced by this way sailed abroad immediately through the international market of bills of exchange. Between 1850 and 1864 the Bank brought-in through those operations on average 17 million ptas each year, while the estimated yearly drain was of near 60 million pts.

${ }^{23}$ I would like to remind the reader that the metallic money supply to which we referred before reflects the 'stock of money of gold and silver', not only the part of this stock used regularly in interchanges. This means that it includes hoarded money in addition to money in 'effective circulation'. So the transfer of hoarded money into normal circulation has to be identified as an increase in the velocity of circulation, as the same amount of money is employed in more transactions.
} 
The Spanish transition from traditional absolutism to a more or less liberal regime was longer and more painful than for other European countries. Furthermore, it coincided with a series of international wars in which Spain found itself involved. Taking into account only the armed conflicts that occurred on the soil of the Iberian Peninsula, we can count almost half a century of continuous turmoil and insecurity from 1791 to 1840. In such circumstances, keeping savings in the form of gold or silver coins was not only prudent but also expedient. As is well known, ransom was used as a way to raise funds by every armed group, regular and irregular groups alike. Having some coin at hand could be a safeguard for people, especially in the countryside.

Furthermore, during this long period, Spanish savers had no access to reliable and remunerative financial instruments. Unlike Britain or France, Spain's governments were unable to sustain the country's growing debt, making government bonds unsuitable for small or medium savers. The early establishment of a modern state-sponsored bank (Banco de San Carlos, 1782) should not mislead us. This bank was created precisely to try to prevent the market value of the increasing public debt from falling. A few years later, the bank found itself trapped in a morass of unpaid government debt and remained comatose until its demise in 1829. On the other hand, no securities other than public debt could be found in the market.

This means that, in addition to the understandable preference of some savers to hoard money for security reasons, others were compelled to do so because they lacked a safe way to place their capital. It may be worth to remind that, beyond current savings, during those years a fair amount of capitals from already emancipated American colonies were repatriated. According the most credible estimates only private transfers received between 1784 and 1820 attained 2.000 million pesetas $^{24}$.

A small normalization occurred after the end of the first Carlist war, in 1840-41. Increasing security encouraged savers to realize that keeping their savings at home in the form of gold coins was no longer necessary or convenient. After years of turmoil, they could consider the possibility of transforming their capital into some kind of profitable investment. Unfortunately, the financial structure was not yet suitable for this shift, nor would it be so for more than a decade.

The main problem was the legal and administrative framework. After the death of Ferdinand VII, in 1832, liberal popular movements helped to set up a new liberal political regime in the midst of the First Carlist War. A large number of regulations and prohibitions were lifted, and formal constitutions replaced absolutist laws. Nevertheless, in some aspects the first wave of liberalization was followed by a restrictive one. This is the case of financial regulation after the crisis of 1847-48. To avoid future problems, conservative governments enacted a number of new laws imposing additional limitations on financial activities.

The Commercial Code of 1829, for instance, was modified in 1848 in order to make it much more difficult to form new mercantile societies with limited liability. In fact, from then on, the government had to approve each application individually and could reject anyone without

\footnotetext{
${ }^{24}$ Cuenca-Esteban (2008, p.335)
} 
having to justify the decision. Some kinds of mercantile societies, such as banks of issue and railway companies, required approval not only by the government but also by Parliament.

The case of banks of issue is a good example of this turnabout in economic policy. Between 1844 and 1846 three proposals to create banks of issue were approved (Bank of Isabella II, in Madrid, and the Banks of Barcelona and Cádiz). After that, however, every new petition was rejected by successive governments for more than a decade. In addition, in 1849 and 1851, new laws forced the three existing banks of issue to diminish drastically the amount of banknotes they were allowed to circulate. Furthermore, the well-known animosity of the conservatives in power toward any kind of expansion of the financial market discouraged all efforts at modernization ${ }^{25}$.

As a consequence of these developments, opportunities for a secure and remunerated placement of savings became as scarce as they were before the end of the war. At the stock exchange in Madrid, founded in 1831, only public debt was traded until the second half of the decade $1850-1860^{26}$. Such opportunities were less scarce in the unofficial Barcelona securities market, but even so, the number of companies listed was very small27. From 1852 on, the demand for financial intermediation and additional means of exchange increased. After the apparent success of the first peninsular railway line (Barcelona to Mataró, opened in 1848), initiatives for new lines flourished, especially in Catalonia. A new mood of expansion spread to international trade and the nascent textile industry. At this point, the underdeveloped and blocked financial system became a major obstacle to growth. This explains why, after the 1854 coup that ousted the conservatives from the government, financial reform became a central political issue.

\section{Loosening the regulatory chains: a clear path to financial expansion}

The new set of financial rules enacted by the progressive party may well be the most controversial and most significant of all the policies implemented during the two years of the so-called 'bienio progresista' . After almost two years of debate, three new laws completely transformed the legal framework of the Spanish financial system: the law of railways ('Ley general de ferrocarriles'); the law of banks of issue ('Ley de bancos de emisión'); and the law of credit societies ('Ley de sociedades de crédito').

Taken together, the new legislation turned the earlier features of the financial market on their head. New joint-stock companies appeared in various sectors and went to public offering, issuing shares and bonds; credit societies also issued bonds in order to help finance new ventures, especially the railways; new banks of issue, for their part, greatly expanded credit by discounting bills of exchange and making loans with securities as a collateral, while at the same time providing banknotes and current accounts as new means of exchange around the country.

\footnotetext{
${ }^{25}$ Sudria and Blasco (2016)

${ }^{26}$ Hoyo $(2007$, p. 153)

${ }^{27}$ Castañeda and Tafunell (2001).
} 
The main drivers of this transformation, however, were the new 'sociedades de crédito'. It is well known that the law that authorized them was tailored to the interests of the three 'sociedades' of French capital named in the law itself. In addition, however, a number of 'indigenous' institutions appeared in several cities.

Despite differences in size and in the markets where they operated, all the credit societies acted alike as financial intermediaries. Most of their operations were related to the main investment of the period, railways, but we can find them in almost every economic sector and dealing with every kind of customer. Their most common operations involved:

Making direct loans to companies, railways or other, essentially short-term, for current operations;

a) Making direct loans to companies or individuals, with companies' securities or public debt as collateral;

b) Discounting bills of exchange or promissory notes to companies or individuals;

c) Accepting current accounts or deposits from companies or individuals, paying interest or not;

d) Acting as contractors for infrastructure companies;

e) Managing and ensuring the issue and placement of companies' shares and bonds, for a commission;

f) Investing directly in companies' securities, and remaining as long-term shareholders and/or bondholders, and

g) Issuing their own bonds or shares.

For our purposes, the most important of these operations were the last three. Representatives of the societies engaged in a door-to-door campaign nationwide to sell securities to any suitable individual who might have hidden savings. Doubtless, the task was not easy. They needed to convince hoarders of the desirability of exchanging gold and silver for the securities of railway companies or credit societies. Their main argument clearly was that the railways themselves were a revolutionary mode of transport. How could it not be profitable to invest in an innovation that was so advantageous for society? Mineral and agrarian products from inland fields and remote regions could now be easily and cheaply transported to seaports. How could such a huge savings in transport costs not yield a decent return? The same could be said of canals and steamboats.

In the case of railways, savings in the form of gold coins flowed to the companies directly (through the sale of their own securities) and indirectly through advancements from credit companies. This gold was not only added to foreign capital to finance railway construction; it also helped to pay for the huge commercial deficit created by massive imports of railway material, from rails to locomotives.

In addition to being credible, could our hypothesis also account for the aforesaid issues? Tedde has conducted an in-depth study of the financial aspects of the railway fever using the records 
of credit societies and railway companies ${ }^{28}$. According to him, the overall investment in railways up to 1867 could have amounted to 1,800 million Ptas. As both the old and the new estimates have attributed 1,200 million to foreign investors, roughly 600 million would be the amount that was financed domestically through the sales campaign mentioned above.

This figure is similar to the one established earlier for "unaccounted-for" investment, which was not financed in 'ordinary' ways. Thus, the placement of railway securities may have been the most important method of mobilizing hoarded gold.

Besides selling railways securities for a fee, the 'sociedades de crédito' also acted as discount houses and credit providers. To attract savers most 'sociedades' issued their own bonds and offered interest bearing deposits. The amount of money that they intermediated by this way was not by any means negligible (see Table 6).

\begin{tabular}{|c|c|c|c|c|}
\hline & & paid-up & & total \\
\hline & & capital & liabilities & assets \\
\hline & number & & Million Pta & \\
\hline Madrid & 9 & 212.5 & 82.5 & 295.0 \\
\hline Barcelona & 5 & 47.5 & 71.3 & 118.8 \\
\hline Valencia & 4 & 6.8 & 8.0 & 14.8 \\
\hline Bilbao & 2 & 10.0 & 23.8 & 33.8 \\
\hline Other & 12 & 31.3 & 34.8 & 66.1 \\
\hline Total & 32 & 308.1 & 220.3 & 528.3 \\
\hline
\end{tabular}

In addition to 'sociedades de crédito' and railways, a new wave of non-financial joint-stock companies was offering placement opportunities to the public. In 1866 the number of nonfinancial nor railways joint-stock companies, amounted to 38 with a total paid-up capital that of almost eighty million pesetas. While still modest, these societies' shares offered an additional way to convert hoarded gold and silver into something more profitable.

Finally, besides being consistent with the data and the events during the years of economic growth, our hypothesis must also be consistent with what we know about the financial collapse of 1866 and beyond. Obviously, this dishoarding process could only continue as long as there were economic agents willing to exchange precious metals for other financial assets. As soon as savers' asset portfolios were adjusted to the offering of new securities, the process would come to an end. Investment would have to match current savings plus foreign net inflows again. This contraction could produce serious financial problems. Shares of railway companies were usually paid in installments, at the request of each company board. When all accumulated savings had been exchanged for securities, investors encountered serious problems in meeting additional installments. As no new money was entering the system, the supply of capital became insufficient to meet companies' requirements. Interest rates went up; companies' shares went down; and bankruptcies spread.

${ }^{28}$ Tedde (1978). 
In these circumstances, several credit societies faced severe difficulties. Their portfolio value fell sharply and distrust spread. As customers sought to withdraw funds, some credit societies were forced to suspend payments. Exhaustion of hoarder's coffers was not the sole cause of the crisis. A couple more worth to be mentioned. Firstly the State ailing finances, market by a secular deficit and by growing difficulties to find fresh resources. Trying to alleviate its dependence from financial intermediaries, the government founded in 1852 the 'Caja General de Depositos', a credit institution devoted to attract private savings to finance the short term needs of the state. With public deficit growing, the 'Caja' ignited the financial market with offerings of higher interest rates, crowding out a large portion of available saving pie ${ }^{29}$.

A second blow to the expansion was the low return offered by railways when the principal lines were completed. From 1864 on became evident that traffic previsions had been grossly overstated, and with them companies' earnings. For most lines, operating margin was insufficient to cover financial costs (securities and credits interests), let alone to remunerate shares. Quotations of companies' shares fell and difficulties aroused for the lines not yet completed to find fresh capital to do so.

The crisis had its main center in Barcelona, where four of the eight existing joint-stock banks and a great deal of mutual banks, and partnerships disappeared. In Spain as a whole only 14 up to the 32 credit societies in existence in 1864 remained in business in 1869. Furthermore, 1866 ' financial crisis opened way to political instability. Two years after, in 1868, a 'progresiste' military uprising forced Queen Isabel II to exile and installed instead an Italian prince, Amadeo de Saboya, which finally had to resign. A short lived republic was proclaimed thereafter, but confronted with an ultraconservative revolt and without popular support, it was finally toppled. The political turmoil did not end until the restoration of the Monarchy, in 1875, under Alfonso XII, Isabel II' elder son.

\section{Rationale of a hypothesis}

The explanation for the Spanish investment boom of mid nineteenth century I am defending here is directly related to a number of relevant research issues, all of them deeply entangled. I could cite among others the genesis and mechanics of financial expansions and crises; the long run behavior of the demand of money and its factors, and the effects of gold hoarding in developing economies. This section is devoted to further analyze some of these issues. Firstly, we look at the ups and downs of investment.

Beyond several particularities, the upward movement of Spanish economy that started in mid1850 s and peaked in mid-1860s fits very well with the so called Kindleberger-Minsky hypothesis ${ }^{30}$. In fact the simultaneous English 'boom' was among the examples cited by Kindleberger in his analysis. Following Minsky's terminology, the initial displacement was in our case clearly related to the offer of railways securities, which attracted both, foreign and domestic investors. The later could contribute through two ways, displacing to railways current

\footnotetext{
${ }^{29}$ Sudrià (2013, p. 140-145)

30 Kindleberger and Aliber (2011, ch. 2); see also Minsky (1977) and Claessens and Kose (2014)
} 
or already invested savings or mobilizing hoarded gold ${ }^{31}$. Unlike in Kindleberger-Minsky narrative, however, there was not in this case an increase in asset prices because capital demand by railways companies was always ahead of available funds. This particular bubble was of quantities not of prices and was probably reinforced by migrants returned to Spain from remaining American colonies, mainly from Cuba ('indianos') ${ }^{32}$. Lacking alternative placements, funds continued to flow until the exhaustion of accumulated savings.

Conversely to the expansion, the financial crisis of 1866 has attracted recently anew the eye of historians. The complexity of the event allows for a diversity of approaches and interpretations that I cannot discuss here in detail ${ }^{33}$. Nevertheless, I would like to comment an innovative one, recently introduced by Moro, Nuño and Tedde (2015) in an article in this journal. Following Bordo terminology the events of 1864-66 are identified by these authors as a 'twin' crisis, simultaneously affecting banks stability and currency markets. Thereafter, they apply new theoretical models of international financial crises with the goal to reconcile the two traditional views of this process: one that blamed a rise of international interest rates as a main driver; and the other that pointed out to domestic factors as the economic failure of the railways or the growing public deficit.

The model considers the mechanics of a typical twin crisis with a sudden stop. The variables and their relationships are well defined and the results fit well with the evidence shown by the main indicators. In my opinion the exercise is interesting and truly helps to understand the complex interactions among multiple variables that characterized the crisis. Accepted this, however, I think the exercise does not allow ruling out the existence of other independent variables beyond international interest rate. For instance it would be possible to introduce a decrease on the velocity of money or an increase in perceived risk by securities holders as external independent moves with effects similar to those identified in the article.

In consequence the hypothesis of a mobilization and subsequent exhaustion of hoarded money could be compatible with the explanation provided by Moro, Nuño and Tedde for the crisis, besides to help understand the great economic expansion that preceded it.

Secondly, the present explanation for the Spanish investment boom of mid nineteenth century is directly related to the debate on the behavior of the demand of money and on factors that influence it. At this respect, what I am stating is that the building of new railways and other infrastructures and somewhat also industrial expansion were partly financed by the mobilization of money hoarded for a long time. Investment surge was larger than current domestic savings and foreign capital entries could afford together. As a consequence, stock of

\footnotetext{
${ }^{31}$ Recently, it has appeared a new wave of papers devoted to the study of investors' behaviour respect to money and credit. The main debate was about rationality of investors during booms. See, for instance, Campbell and Turner (2012); and Greenwood and Nagel (2009). Unfortunately, Spain lacks detailed studies about the personality and behaviour of railways investors beyond credit societies. There are some studies about ownership structure of several companies, but mostly centered on the disputes for control among largest shareholders: see Comín et alia (1998, I, pp.177-192); Vidal (1999); and Galí (2001).

32 Several studies show that railways' stocks and bonds took a good share in the composition of these 'indianos' portfolios, probably in substitution of gold or silver brought in at their return. See Bahamonde and Cayuela (1992) and Rodrigo $(2007,2015)$

${ }^{33}$ See, for instance, Navas and Sudrià (2008); Martín-Aceña and Nogués-Marco (2013); Sudrià (2013); and Tedde (2015, pp. 259-327)
} 
gold and silver (and money supply) fell, apparently by almost a half. However we cannot detect any signs of deflation, although there were occasional increases in interest rates.

My proposition is that this fall in the money stock was offset by an increase in the velocity of circulation. In other words, the mobilization of hoarded savings allowed a similar number of transactions to be made with less money or, alternatively, the increase in the velocity of money made some amount of metallic money redundant. This ' $\mathrm{g}$ ift' made it possible to finance a temporary external deficit and also funded a part of the building of the railways.

The behavior of the velocity of money described above runs contrary to that proposed for this period by Albert Carreras and co-authors in a paper published in $2006^{34}$. This is not surprising if we take into account their acceptance of Tortella's estimate of the stock of metallic money. As we have already seen, the new estimates of foreign transactions led to an amount of the stock of money in 1850 of around 1.700 million pesetas instead of the 600 million calculated by Tortella. That means that the expected velocity ratio of 7,1 would be reduced to 2,5 , to be compared with the 4,4 attained in 1874. It seems to me that those new estimates could be more credible for a country that was just beginning its modernization process. It is worth to recall that before the progressive laws of 1856 only three cities have joint-stock banks and circulation of paper money. In any case the new ratio is close to that of Norway around 1880, a country that had then a similar level of per capita income than Spain ${ }^{35}$.

Despite being more consistent with the available data and with what we know about monetary market fluctuations and external Spanish relationships in those years, it is true that our proposal places Spain in almost the opposite direction with respect other European countries. As is well known, Michael Bordo and Lars Jonung have studied the long-term evolution of the velocity of money in several developed countries, and the factors behind $\mathrm{it}^{36}$. They identify two forces that have shaped the evolution of the velocity of money in addition to the traditional determinants, real income and the interest rate. The first one is the process of monetization that reflects the spread of the money economy; the second, financial sophistication and improved economic stability. The first tends to push velocity downwards, as monetary transactions grow faster than production. The second pushes it upwards, as new financial products and less instability allow for the substitution of money for other products in a variety of uses.

Bordo and Jonung have built estimates of the velocity of money for several countries from 1870 onwards, identifying a similar pattern in most of them. From the beginnings of the estimates to somewhere between the 1920s and 1940s, velocity falls; then it changes direction and begins to rise. According to Bordo and Jonung's interpretation, "the monetization effect first dominates causing velocity to fall. Later the influence of financial development and improved stability is stronger... causing velocity to rise ${ }^{\prime 37}$. Institutional factors are pointed out

\footnotetext{
${ }^{34}$ Carreras, García-Iglesias, and Kilponen (2006).

35 Bordo and Jonung (2004); Maddison (2003, p. 61-67). Such an important change in the estimated stock of money for 1850 would introduce new perspectives on the tentative approaches to monetary aspects of Spanish economy evolution during the first half of ninetieth century. See Tedde (2009)

${ }^{36}$ Bordo and Jonung (1981, 1987, 1990, and 2004).

37 Bordo and Jonung (2004), pp. 149-150
} 
as the main drivers of these changes, and the authors try to verify this hypothesis through several regressions.

This interpretation helps to understand Spanish opposite results. It should be noted that the countries analyzed by Bordo and Jonung were already financially advanced in the midnineteenth century. That means that mobilization of hoarded gold had already occurred in an earlier period. Bordo and Jonung are right pointing out to monetization as the prime mover of velocity decline after 1870 . The forces that shaped the first period of institutional adjustment had faded in these countries, while they were still predominant in Spain.

In some sense, financial backwardness helped to retain saved resources until the arrival of a new and revolutionary innovation, the railways, required them. Unfortunately for those patient savers who had waited so long, dazzling technical novelties do not always secure healthy returns for those who invest in them.

Finally, I would like to address the crucial issue of hoarding gold and the effects on the real economy of its volume and fluctuations. The most famous mention to the issue is probably the invective directed by Keynes to the Indian people inclination to hold gold and silver, a "needless accumulation" and an "uncivilized and wasteful habit"38.

He did not elaborate, however, on existing hoarding of gold in advanced countries neither on the effects of its reduction ${ }^{39}$. Nevertheless, a gradual replacement of liquid assets (gold, silver) by financial assets in agents' portfolios was a process that took place in all advanced countries at a certain stage in their economic development. Renowned authors writing during the interwar period were well aware of these phenomena and tried to explain it. This is the case of Alfred Marshall in his Money, Credit and Commerce $(1923)^{40}$.

However, the most precise approach was that of Knut Wicksell in his Lectures on Political Economy (1934). According to Wicksell the level of hoarding would be related, on one hand, to the degree of insecurity felt by the society at a specific moment and, on the other hand, to the alternative ways to allocate savings safely". Following this logic, the introduction of new financial instruments or improvements in financial markets (liquidity, a reduction in transaction costs, etc.) could encourage changes in the behavior of savers:

"Owing to the development of credit, private hoarding has fallen almost entirely into desuetude in the more progressive countries and has been replaced by a more economic method of storing value. The money capital saved, usually through the medium of banks and savings banks, is loaned as quickly as possible and is thereby returned to circulation. From the individual's point of view, this means the transformation of dead capital into fruitful capital".

\footnotetext{
${ }^{38}$ Keynes (1913, p. 99). Several authors, mostly Indians, have refuted Keynes opinion while defending that hoarding habits and monetary system performance are not related. See, for instance, Chandavarkar (1961).

${ }^{39}$ Keynes advised, however, against any sudden 'disgorge' of Indian gold that "may involve the world in a very great inflation" (p.101)

${ }^{40}$ Marshall (1923, I, pp. 42-45)
} 
This change in the demand for metallic money by the public had significant effects on the economy as a whole:

"On the other hand... the general economic advantage of this arrangement is, broadly speaking, very considerable.... making all existing stocks of money available for circulation. That, of course, would be a great advantage to any individual country, for the money which was not required in circulation could be, and in fact automatically would be, sent abroad in exchange for goods or as interest bearing loans" ${ }^{\prime 11}$.

In other words, the decline in the demand for metallic money provides the economy as a whole with purchasing power abroad that can be used to increase imports. Note that this is a one-time phenomenon that can occur gradually, as a consequence of a smooth process of financial modernization, or suddenly, if the institutional changes are sudden. And if there is a latent demand for new financial instruments, the effect can be even greater. In our opinion, these were the circumstances surrounding the Spanish case. The laws of 1856, in this context, led to a genuine financial revolution, with important effects on the economy as a whole.

\section{Conclusions}

To conclude I would like to summarize briefly the hypothesis arisen in the precedent sections. New estimates show that the amount of foreign capital that arrived in Spain during the 'railway era' (1856-1874) was smaller than previously thought. This fact implies that a significant part of the period's investment could not be financed solely by current internal savings and foreign capital entries. How the outstanding financial need was met had to be linked to an outstanding decrease of demand for money, which assured more interchanges with less physical money.

To a large extent, this change took the form of massive purchases of securities of railways companies or credit societies by the public in return for previously saved and hoarded gold or silver. 'Sociedades de crédito' were probably the main agents of this small revolution. The state contributed to this flow through direct investment in diverse infrastructures (not only railways), mostly financed increasing the public debt.

This kind of transition from hard money (or coinable metals) to securities as a way to store value had to occur in every country, but usually more gradually than in Spain and often obscured by other developments. Political circumstances explain the distinctive Spanish timing. Nevertheless similar argument could help to understand some demand for money unexpected behavior on less advanced countries.

The rationale here introduced is compatible with the new analysis of financial crises derived from modern monetary models. I think that both approaches could be complementary if hoarding and dishoarding (or exogenous changes in velocity of money) are introduced in the model as an independent variable.

This hypothesis comes to reinforce the idea that Spanish domestic savings played a more decisive role in the first wave of economic modernization than previously thought.

${ }^{41}$ Wicksell $(1934$, II, p. 9-10) 


\section{Acknowledgments}

The author wants to express his sincere thanks to Pere Pascual for having shared a first alert on the old coffers and for a long, generous, and fruitful association and friendship. Suggestions from three anonymous referees and an associate editor have contributed greatly to avoid mistakes and to improve the paper. Financial support of the Centre d'Estudis 'Antoni de Capmany', Universitat de Barcelona (Generalitat de Catalunya, research group 2014 SGR 1345) and the Spanish Ministry of Economy and the European Regional Development Fund (project HAR2015-64769-P) is gratefully acknowledged. 


\section{REFERENCES}

BAHAMONDE, A. and CAYUelA, J. (1992): Hacer las Américas. Las élites coloniales españolas en el siglo XIX. Madrid, Alianza.

BoRDO, M.D. and JonUnG, L. (1981): "The Long Run Behavior of the Income Velocity of Money in Five Advanced Countries, 1870-1975: An Institutional Approach," Economic Inquiry, vol. 19(1), pages 96-116.

BORDO, M. D. AND JonUNG, L. (1987): The Long-Run Behavior of the Velocity of Circulation: The International Evidence, New York, Cambridge University Press.

BORDO, M.D. AND JONUNG, L. (1990): "The long-run behavior of velocity: The institutional approach revisited," Journal of Policy Modeling, vol. 12(2), pages 165-197.

BORDO, M.D. AND JONUNG, L. (2004): Demand for Money. an analysis of the long-run behavior of the velocity of circulation. New Brunswick, NJ ; London : Transaction Publishers.

BRODER, A. (1976), "Les investissements étrangers en Espagne au XIXème siècle: methodologie et quantification", Revue d'Histoire Économique et Sociale, LIV, 1, pp. 29-63.

BRODER, A. (1981), Le rôle des investissements étrangers en Espagne, 1767-1924," 7 vol. Thèse, Univ. de Lille III.

CAMPBelL, G. and TURNeR, J.D. (2012), "Dispelling the Myth of the Naife Investor during the British Railway Mania. 1845-1846". Business History Review, 86, pp. 3-41.

CARreras, A. (2004), "Nota bibliográfica: Leandro Prados de la Escosura. El progreso económico de España (1850-2000)", Revista de Historia Económica, 22, 2, 501-514.

CARRERAS, A., GarcíA-IGLESIAS, C., AND KILPONEN, J. (2006), "Un siglo y medio de velocidad de circulación del dinero enEspaña. Estimación y determinación”, Revista de Historia Económica, XXIV, 2, 215-249.

CARreRAS, A. and TAfunelL, X. (2010), Historia Económica de la España contemporánea. Barcelona, Crítica.

CASTAÑEDA, LL. and TAFUnelL, X. (2001), "La Bolsa de Barcelona entre 1849 y 1913: un nuevo índice", in C. Sudrià, and D.A. Tirado, eds., Peseta y protección. Comercio exterior, moneda y crecimiento económico en la España de la Restauración. Barcelona: Edicions de la Universitat de Barcelona, pp. 208-236.

Chandavarkar, A.G. (1961): "The Nature and Effects of Gold Hoarding in Under-developed Economies", Oxford Economic Papers, 12, 2, pp.137-148.

CLAESSENS, S. and KOSE, M.A., "Financial Crises: Explanations, Types, and Implications", in S. Claessens; M.A. Kose; L. Laeven; and F. Valencia, eds., Financial Crises: Causes, Consequences, and Policy Responses. Washington: International Monetary Fund, pp. 3-61. 
Сomín, F. (1985), Fuentes cuantitativas para elestudio del sector público en España, 1801-1980. Madrid: Instituto de Estudios Fiscales.

ComiN, F. (1988), Hacienda y economia en la España contemporània (1800-1936). Madrid: Instituto de Estudios Fiscales, 2 vols.

Comín, F. (2016), La crisis de la deuda soberana en España (1500-2015). Madrid: Catarata.

ComIN, F. et alia (1998), 150 años de historia de los Ferrocarriles españoles. Madrid: Fundación de los Ferrocarriles espanyoles, 2 vols.

Cuenca-Esteban, J. (2008), "Statistics of Spain's Colonial Trade, 1747-1820. New Estimates and Comparisons with Great Britain", Revista de Historia Económica/Journal of Iberian and Latin America Economic History, XXVI, 3, pp. 323-354.

GALÍ, R. (2001), "L'estructura de capital de les companyies de ferrocarril catalanes, 1844-1873", Recerques, 42, pp. 89-124.

GREENWOOD, R., and NAGEL, S. (2009): "Inexperienced Investors and Bubbles", Journal of Financial Economics, 93, pp. 239-

HERRANZ-LonCÁN. A. (2004), La dotación de infraestructuras en España, 1844-1935. Estudios de Historia Económica, n. 45. Madrid, Banco de España.

HoYo, A. (2007): Economía y mercado de valores en la España contemporánea. Santander, Universidad de Cantabria.

KEYNES, J. (1913), Indian Currrency and Finance. London, MacMillan.

Kindleberger, CH. P. and Aliber, R.B. $\left(2011^{6}\right)$, Manias, Panics, and Crashes: A History of Financial Crises, New York: Palgrave MacMillan.

MADDISON, A. (2003), The World Economy: Historical Statistics. Paris, OECD.

MALUQUeR DE MOTES, J. (2005a), “¿Cuánto, y cuándo, progresó la economia española moderna? La Contabilidad Nacional retrospectiva de Prados de la Escosura", Revista de Historia Industrial, 28, pp. 189-200.

Maluquer de Motes, J. (2005b): "Comsumo y precios", in A. Carreras and X. Tafunell, Estadísticas Históricas de España. Madrid: Fundación BBVA, 2nd Edition, pp. 1247-1296.

MARShAlL, A. (1923): Money, Credit, and Commerce, London, Macmillan.

MARTín ACEÑA, P. (2000), "The Spanish Monetary Experience, 1848-1914", in P. Martín Aceña, and J. Reis, eds., Monetary Standards in the Periphery. Paper, Silver and Gold, 1854-1933, London: MacMillan, pp. 112-150.

MARTín ACEÑA, P. and Pons, M.A. (2005): "Sistema monetario y financiero", in A. Carreras and X. Tafunell, Estadísticas Históricas de España. Madrid, Fundación BBVA, 2nd Edition, pp. 647-706. 
Martín AceÑA, P. and Nogués-Marco, P. (2013), “Crisis bancarias en la historia de España. Del Antiguo Régmen a los orígenes del capitalismo moderno", in F. Comín, and M. Hernández, eds., Las crisis económicas en España, 1300-2012. Lecciones de la historia. Madrid, Alianza, pp. 141-167.

Moro, A.; NUÑo, G., and TEDDE, P. (2015): "A twin crisis with multiple banks of issue: Spain in the 1860s". European Review of Economic History, 19, pp. 171-194.

MINSKY, H. (1977), "A Theory of Systemic Fragility". In E.J. Altman, and A.W. Sametz, eds., Financial Crises: Institutions and Markets in a Fragile Environment. New York: Wiley, pp. 138152.

NADAL, J. (1973), "The Failure of the Industrial Revolution in Spain, 1830-1913", in C.M. Cipolla, ed. The Fontana Economic History of Europe, t. 4 (2). London, Collins Publishers. pp. 533-626.

NADAL, J. (1975), El fracaso de la Revolución industrial en España, 1814-1913. Barcelona: Ariel.

NADAL, J.; BENAUL, J.M., and SUDRIÀ, C. dirs. (2012), Atles de la Industrialització de Catalunya, 1750-2010. Barcelona: Vicens Vives.

NAVAS, M., and SUDRIÀ, C. (2008): "La crisi financera de 1866 a Barcelona. Una revisió", Recerques, 55, pp. 35-72.

PASCUAL, P. (1990): Agricultura i industrialització a la Catalunya del segle XIX, Barcelona, Crítica. PASCUAL, P.(1999): Los caminos de la era industrial. La construcción y financiación de la Red Ferroviaria Catalana (1843-1898). Barcelona, Edicions Universitat de Barcelona.

Prados, L. (1986), “Una Serie Anual del Comercio Exterior Español (1821-1913)». Revista de Historia Económica, 4, 1, 103-150.

PRADOS, L. (2003), El progreso económico de España (1850-2000). Madrid: Fundación BBVA.

Prados, L. (2010), "Spain's International position, 1850-1913", Revista de Historia Económica, $28,1,173-215$.

Prados, L. and RosÉs, J.R., (2009), "The Sources of Long-Run Growth in Spain, 1850-2000," The Journal of Economic History, vol. 69 (04), pp. 1063-1091.

RodRIGo, M. (2007), Indians a Catalunya: Capitals cubans en l'economia catalana. Barcelona, Fundació Noguera.

RodRIGO, M. (2015), “From Periphery to Centre: Transatlantic Capital Flows, 1830-1890". In A. Leonard, and D. Petrel, eds., The Caribean and the Atlantic World Economy. Circuits of Trade, Money and Knowledge, 1650-1914. New York: Palgrave MacMillan, pp. 217-237.

SÁNCHEZ-ALBORNOZ, N. (1962) "La crisis de 1866 en Barcelona (notas para su estudio)», in Homenaje a D. Ramón Carande, Madrid. Sociedad de Estudios y Publicaciones, vol II, pàg. 421436. 
SARDÀ, J. (1948), La política monetaria y las fluctuaciones de la economía española en el siglo XIX. Madrid: Instituto Sancho de Moncada.

SUDRIÀ, C. (2013): "La crisis de 1866. El estado, los ferrocarriles y los bancos", in J. A. Gutiérrez Sebares and F. J. Martínez García, eds., Cinco estudios sobre crisis económicas en la historia de España. Cuadernos de Investigación UCEIF, n. 10. Santander, Ediciones de la Universidad de Cantabria, pp. 129-164.

SUDRIÀ, C., and PASCUAL, P. (1999): “Financiang a railway mania: capital formation and the demand for Money in Catalonia, 1840-66", Financial History Review, 6, pp. 127-245.

SUDRIÀ, C., and BLASCO, Y. eds. (2016), La pluralidad de emisión en España (1844-1874). Madrid: Fundación BBVA.

TEDDE, P. (1978): “Las compañías ferroviarias en España, (1855-1939)”, in Artola, M., dir., Los Ferrocarriles en España, 1844-1943, Madrid, Servicio de Estudios del Banco de España, vol. II, pp. 1-354.

TedDE, P. (1999), El Banco de San Fernando, 1829-1856. Madrid: Banco de España.

TEDDE, P. (2009), “Oro y plata en España: un ensayo de cuantificación (1770-1850). La economia monetària espanyola y la independència de América", in Llopis, E. and Marichal, C., eds., Latinoamérica y España, 1800-1850. Un crecimiento económico nada excepcional. Madrid, Marcial Pons/Instituto Mora, pp. 211-252.

TEDDE, P. (2015), El Banco de España y el Estado Liberal (1847-1874), Madrid, Banco de España/Gadir.

TORTELLA, G. (1973), Los orígenes del capitalismo en España. Banca, industria y ferrocarriles (1829-1874). Tecnos, Madrid.

TORTELLA, G. (1977), Banking, Railroads, and Industry in Spain (1829-1874). New York, Arno Press.

Tortella, G. (1983), "National Income Estimation by Means of Monetary Variables, the Case of Spain, 1772-1972. Some Preliminary Results", in Fremdling R. and O'Brien, P., eds., Productivity in the Economies of Europe. Sttugart, Klett-Cotta.

ToRTella, G. (2010), The Development of Modern Spain. An Economic History of the Nineteenth and Twentieth Centuries. Harvard, Harvard University Press.

VIDAL, J. (1999). “La estructura de la propiedad, la organización y la gestión de una gran empresa ferroviaria: la Compañía de los Caminos de Hierro del Norte de España, 1858-1936“, Revista de Historia Económica, XVII, 3, pp. 623--662

WICKSELL, K. (1934); Lectures on Political Economy. London, Routledge and Sons 